\title{
Biedni emigranci patrzą na getto. OSmoczej 13 Stefanii Zahorskiej
}

Jakub Osiński

TEKSTY DRUGIE 2018, NR 3, S. 399-417

DOI: 10.18318/td.2018.3.28

Cmocza 13, jeden z dwu dramatów autorstwa Stefanii Zahorskiej (1890-1961)', jest dziś dziełem zapomnianym, tak samo jak jego autorka. O ile jednak przyczyn absencji Zahorskiej w szerszej świadomości badawczej i - przede wszystkim - społecznej, mimo podjętych w ostatnich latach starań o zmianę tego status $q u o^{2}$, trudno dochodzić, o tyle brak zainteresowania literaturoznawców dramatem, o którym tu mowa, można wytłumaczyć dwoma niepokojącymi fenomenami. Po pierwsze, dramat i teatr wychodźstwa i emigracji, zwany - za Leopoldem Kielanowskim - dramatem i teatrem

1 Drugi z nich, zatytułowany Zdrada Joanny, nie został dotąd wydany. Maszynopis z odręcznymi poprawkami autorki przechowywany jest w archiwum londyńskiego Związku Artystów Scen Polskich za Granicą (ZASPzG), znajdującym się obecnie w Instytucie Teatralnym im. Z. Raszewskiego w Warszawie.

2 Zob. A. Pilch Symbolika form i kolorów. O krytyce artystycznej Stefanii Zahorskiej, Księgarnia Akademicka, Kraków 2004; S. Zahorska Wybór pism. Reportaże, publicystyka, eseje, wyb., wstęp i oprac. A. Nasiłowska, Wydawnictwo IBL PAN, Warszawa 2010.
Jakub Osiński - lic., student filologii polskiej na Uniwersytecie Mikołaja Kopernika w Toruniu. Szkice i recenzje publikował m.in. w: „Tekstach Drugich”, Przeglądzie Humanistycznym", "Kontekstach Kultury", "Polonistyce" oraz książkach zbiorowych. Interesuje się teorią i historią literatury XX w., szczególnie autobiografistyką i literaturą Drugiej Emigracji. Kontakt: jakubosinski@vp.pl. 
heroicznym (1939-1945) i służebnym (1945-1989)³, choć był przedmiotem zainteresowania badaczy jeszcze kilkanaście lat temu, dziś już zdecydowanie pozostaje poza refleksją teatrologów i literaturoznawców. Po drugie zaś, Holokaust czy relacje polsko-żydowskie ukazywane w literaturze wychodźczej i emigracyjnej pozostają dotychczas słabo opisane, mimo że - jak słusznie zauważa Sławomir Buryła - „zbiór utworów powstałych na emigracji i traktujących o Zagładzie jest o wiele skromniejszy niż ten, którym

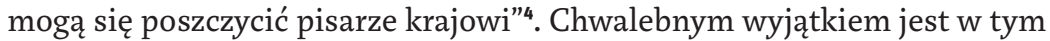
kontekście książka Kazimierza Adamczyka, jednak stanowi ona co najwyżej punkt wyjścia do dalszych badań5. Wobec tego stanu rzeczy trudno się dziwić, że Smoczej13 - dramatowi powstałemu na wychodźstwie i dotyczącemu getta warszawskiego - historycy literatury poświęcali dotychczas uwagę marginalnie ${ }^{6}$.

Niniejszy szkic ma stanowić możliwie wyczerpujące studium dramatu, uwzględniające także okoliczności jego powstania i recepcję. Wywód ten będzie miał charakter historycznoliteracki, nie zaś - teatrologiczny, jako że Smocza 13 nie została nigdy wystawiona w teatrze, a przynajmniej nic na ten temat nie wiadomo. Ponadto, uprzedzając płynące z tej analizy wnioski, należy zaznaczyć, że podobnie jak gros dramaturgii wychodźczej i emigracyjnej, tak i omawiany utwór pod względem artystycznym nie jest osiągnięciem wybitnym. Warto jednak poświęcić mu uwagę ze względu na miejsce, jakie zajmuje w twórczości Zahorskiej oraz w literaturze poświęconej doświadczeniom polsko-żydowskim powstającej na obczyźnie. A jest to - jak się zdaje - w obu wypadkach miejsce szczególne.

Dla porządku przypomnijmy, że Stefania Zahorska - w okresie międzywojennym nie tylko pisarka i reportażystka, współpracowniczka, m.in. „Wiadomości Literackich”, ale i krytyczka sztuki,jedna z pierwszych polskich

3 L. Kielanowski Teatr służebny, w: Polskie więzi kulturowe na obczyźnie, red. M. Paszkiewicz, Polskie Towarzystwo Naukowe na Obczyźnie, Londyn 1986, s. 128. Zob. także D. Ratajczakowa Dramat nieobecny, "Dialog" $1992 \mathrm{nr} 3$.

4 S. Buryła "Siostry" Barbary Toporskiej - opowieść o dwóch losach, w: tegoż WokółZagłady. Szkice o literaturze Holocaustu, Universitas, Kraków 2016, s. 263.

5 K. Adamczyk Doświadczenia polsko-żydowskie w literaturze emigracyjnej (1939-1980), Wydawnictwo UJ, Kraków 2008.

6 Najszerzej o dramacie pisała jak dotąd E. Popławska-Cibicka Zagęszczenie znaczeń w judaicach Stefanii Zahorskiej, „Orbis Linguarum. Legnickie Rozprawy Filologiczne” 2015 vol. 43, s. 423-427. Badaczka w swoim odczytaniu nie uwzględnia jednak, niestety, ważnych ustaleń Adamczyka oraz problemów związanych z wydaniem i dramatu, o których pisze Nasiłowska. 
krytyczek filmowych - opuściła kraj w 1939 roku. Przez Lwów, Bukareszt i Paryż, gdzie współpracowała z „Polską Walczącą” i „Wiadomościami Polskimi", w 1940 roku dotarła, wraz ze swoim wieloletnim partnerem, Adamem Pragierem, do Londynu. Pragier, przed wojną związany z PPS, był ministrem informacji i dokumentacji w wychodźczych rządach Tomasza Arciszewskiego i Tadeusza Komorowskiego.W ministerstwie tym pracowała także Zahorska:

powierzono jej - sprawozdaje Anna Nasiłowska - zadanie pisania listów i sprostowań do międzynarodowej prasy, wszędzie, gdzie trzeba było reagować na nieścisłości, niekompetencje czy niekorzystne opinie dotyczące Polski. W 1941 r[oku] napisała ona 103 listy do gazet: oświetlając stanowisko rządu polskiego, polską rację stanu, sprawę Żydów w Polsce i stosunek do ZSRR.?

Jak wolno przypuszczać, właśnie z tych doświadczeń zrodził się pomysł napisania dramatu. Impulsem bezpośrednim, według relacji Lidii Ciołkoszowej przekazanej Mai Elżbiecie Cybulskiej, miała być natomiast samobójcza śmierć Szmula Zygielbojma (12 maja 1943 roku) w geście sprzeciwu wobec przyzwolenia Zachodu na Zagładę?. O samych okolicznościach powstania i wydania utworu wiemy jednak niewiele. Jak na ten temat pisze Nasiłowska:

Dramat Smocza 13 czytany był na zebraniu polskiego PEN Clubu 28 marca 1944. O innym jego wykorzystaniu nie wiadomo. Jego druk (a w takiej

7 A. Nasiłowska Stefania Zahorska i wiek XX, w: S. Zahorska Wybór pism..., s. 31. Zob. także tejże Maria Kuncewiczowa i Polski PEN Club 1939-1941, w: Polski PEN Club 1925-2005. Księga pamiq̨tkowa, red. A. Pomorski, Open, Warszawa 2005, s. 313-314. Wszystkie przypisy w tekście pochodzą od autora.

8 M.E. Cybulska Potwierdzone istnienie. Archiwum Stefanii Zahorskiej, Polska Fundacja Kulturalna, Londyn 1988, s. 124 [przyp. 2].

9 O znaczeniu tej śmierci dla Zahorskiej mogą pośrednio świadczyć słowa Pragiera: „najbardziej wstrząsające dla nas było samobójstwo Szmula Zygielbojma, przedstawiciela «Bundu» w Radzie Narodowej w Londynie. Odebrał sobie życie dla zaprotestowania przeciwko ludobójstwu popełnianemu przez Niemców na Żydach. [...] Otrzymywał z kraju częste sprawozdania, które jednak nie budziły w świecie wiary i zrozumienia. Bo też to, co było w tych sprawozdaniach, przechodziło ludzką wyobraźnię. [...] O tej mojej niewierze w wiadomości podawane przez Zygielbojma wspominam z żalem oraz ze wstydem". Jest to przy tym doskonałe świadectwo tego, jaka w pierwszych latach wojny była świadomość polskich wychodźców na temat Holokaustu. A. Pragier Czas przeszły dokonany, B. Świderski, Londyn 1966, s. 844-845. Pisownię uwspółcześniono. 
wersji przetrwał) spowodował bardzo poważny konflikt z wydawca, którym była redagowana przez [Antoniego] Słonimskiego „Nowa Polska”, choć wydawnictwo reprezentowała też inna osoba. Bez upoważnienia autorki wprowadzono daleko idące zmiany w tekście. [...] Skierowała [Zahorska] 1 maja 1945 do wydawcy list protestacyjny, zakazując wręcz rozpowszechniania książki w obiegu księgarskim, powiadamiając o tym oficjalnie PEN Club i Ministerstwo Informacji (czyli Pragiera, który naturalnie dobrze o tym już wiedział prywatnie). Sprawa ta nie przesądziła o odebraniu dotacji „Nowej Polsce”, były inne konflikty, z pewnością jednak nie poprawiła stosunków. [...] Potem podejmowała próby zainteresowania wytwórni Metro Glodwyn Meyer [sic!] swoim dramatem jako materiałem na film, jednak podobnie jak inne, wcześniejsze próby polskiej emigracji, nie przyniosło to jednak rezultatu. ${ }^{\mathbf{1 0}}$

Kilka faktów przedstawionych przez badaczkę wymaga sprostowania. Smocza 13 była nie tylko czytana na spotkaniu zorganizowanym przez polski PEN Clubu, w marcu 1944 roku"1, ale i - w Ognisku Polskim w Londynie, w maju lub czerwcu. Z pierwszej prezentacji zdawał relację Tymon Terlecki na łamach „Dziennika Polskiego i Dziennika Żołnierza”12. O odczytaniu dramatu w Ognisku Polskim wspominał zaś w jerozolimskim dwutygodniku „W Drodze" Henryk Schoenfeld, londyński korespondent pisma ${ }^{13}$. Wiadomo także, że Zahorska starała się o wystawienie Smoczej 13 w Tel Awiwie, w słynnym Teatrze Habima, co wynika z jej korespondencji z Wiktorem Weintraubem ${ }^{14}$.

10 A. Nasiłowska Stefania Zahorska i..., s. 37.

11 Według relacji Terleckiego mieli wówczas wystąpić: Maria Balcerkiewicz, Mila Kamińska, Tola Korian, Szczepan Baczyński, Karol Dorowski oraz członkowie Lotniczej Czołówki Teatralnej, którą kierował wówczas Stanisław Zięciakiewicz. A.). [T. Terlecki] „Smocza 13”. Dramat Stefanii Zahorskiej, "Dziennik Polski i Dziennik Żołnierza” 1944 nr 85 (12 kwietnia), s. 3. Na marginesie należy dodać, że bibliografie (por. J. Czachowska, M.K. Maciejewska, T. Tyszkiewicz Literatura polska i teatr w latach II wojny światowej, t. 3, Ossolineum, Wrocław 1986, s. 109) i słowniki biobibliograficzne (por. B. Dorosz Stefania Zahorska, hasło w: Współcześni polscy pisarze i badacze literatury, red. J. Czachowska, A. Szałagan, WSiP, Warszawa 2004, s. 358), odnotowując ten tekst, błędnie przypisują jego autorstwo Aleksandrowi Jancie-Połczyńskiemu, tak samo, jak Popławska-Cibicka (Zagęszczenie znaczeń w..., s. 423 [przyp. 10], 432 [bibliografia]). „A.J." to inicjały pseudonimu Terleckiego - Aleksander Janowski.

A.J. [T. Terlecki] „Smocza 13”. Dramat..., s. 3.

H.S. Dominik [H. Schoenfeld] „Smocza 13", „W Drodze” 1944 nr 12 (16 czerwca), s. 11.

M.E. Cybulska Potwierdzone istnienie. Archiwum..., s. 124 [przyp. 2]. 
Ponadto o odczytaniu dramatu w 1961 roku, w londyńskim Związku Pisarzy Polskich na Obczyźnie, wzmiankował Kielanowski; tej informacji nie udało się jednak, niestety, potwierdzić' ${ }^{15}$. Dodać należy, że utwór został przetłumaczony na język angielski, co niewątpliwie wiązało się z próbami zaprezentowania go poza środowiskiem polskich emigrantów ${ }^{16}$.

Anna Nasiłowska wspomina ponadto o liście protestacyjnym, który do redakcji „Nowej Polski” (oraz PEN Clubu i Ministerstwa Informacji i Dokumentacji) miała wysłać Zahorska 1 maja 1945 roku; nie podaje jednak źródła tej informacji. Zachowały się z pewnością listy Zahorskiej i Marii Kuncewiczowej z czerwca tego roku. Wynika z nich, że Zahorska chciała, żeby jej konflikt ze Słonimskim rozstrzygnęła specjalna komisja powołana przez PEN Club, któremu przewodniczyła wówczas Kuncewiczowa ${ }^{17}$. Wymowne jest - wykreślone przez Zahorską - zakończenie tego listu:

Ostatecznie trudno zrobić coś gorszego autorowi, jak zabić mu książkę. To jest oczywiście tylko uwaga prywatna, która nie musi nikogo obowiązywać. Obowiązująca wydaje mi się tylko obiektywna i równa lojalność wobec wszystkich członków PEN Clubu. Tak samo - na szerszej płaszczyźnie - obowiązująca wydaje mi się dbałość o dobre obyczaje pisarskie. ${ }^{18}$

Na list Zahorskiej Kuncewiczowa odpowiedziała:

Jeśli Słonimski stanął przed kwestią jako wydawca, nie redaktor, nie podpada pod nasze kompetencje. Nie jest zresztą wydawcą, jest nim [?] Niziński czy [Feliks] Gadomski. Na to powiedziano mi, że Słonimski porobił zmiany w tekście nie porozumiawszy się z Panią. $\mathrm{Na}$

15 L. Kielanowski Słowo i ciało. Scenopisarstwo polskie na uchodźstwie, „Pamiętnik Literacki” (Londyn) 1976, s. 93. W archiwum ZASPzG nie zachowały się żadne świadczące o tym dokumenty. Możliwe zatem, że informacja podana przez Kielanowskiego jest błędna.

M.E. Cybulska Potwierdzone istnienie. Archiwum..., s. 124 [przyp. 2]. Anonimowy przekład dramatu, według relacji Cybulskiej, miał znajdować się w archiwum ZASPzG, które w 2008 roku trafiło do Instytutu Teatralnego im. Z. Raszewskiego w Warszawie. Tam, niestety, owego przekładu nie udało się odnaleźć podczas kwerendy. Być może nie trafił on do Warszawy. W każdym razie obecne miejsce jego przechowywania jest nieznane.

18 Tamże, s. 127 
to odpowiedziałam: „a jeśli tak jest, to co innego”. Na tym się sprawa skończyła i nie sądzę, żebym popełniła najdrobniejszą chociażby nielojalność wobec Pani. ${ }^{19}$

Należy powtórzyć za Nasiłowską, że nie wiadomo nic na temat rozstrzygnięcia sporu między Zahorską i Słonimskim, stąd można uznać, że stanowisko wyartykułowane przez Kuncewiczową w przywoływanym liście było przez nią konsekwentnie podtrzymywane i ostatecznie PEN Club nie wyciągnął żadnych konsekwencji wobec redaktora „Nowej Polski”.

Warto zwrócić tu szczególną uwagę na to, że z przywoływanych listów nie wynika, o którym wydaniu dramatu mowa; są one datowane na czerwiec 1945 roku, a wówczas Smocza 13 była opublikowana dwukrotnie: po raz pierwszy w 1944 roku, w numerach 9 i 10 „Nowej Polski”, a więc zapewne we wrześniu i październiku ${ }^{20}$, po raz drugi zaś w wersji książkowej w maju $1945 \mathrm{roku}^{21}$. Na podstawie informacji Nasiłowskiej o liście protestacyjnym, który Zahorska miała wystosować 1 maja, oraz przywołanej chronologii można zatem przypuszczać, że zarzuty Zahorskiej dotyczyły owej drugiej, książkowej publikacji. Między listopadem 1944 roku a majem roku następnego zarząd PEN Clubu spotykał się z pewnością kilkakrotnie, a mimo to nie ma materiałów, które wskazywałyby na to, że Zahorska domagała się na którymkolwiek z tych spotkań zaangażowania innych pisarzy w swój zatarg ze Słonimskim.

Jest to przypuszczenie o tyle ważne, o ile weźmie się pod uwagę, że ze względu na brak materiałów, które miały dotyczyć zarzutów Zahorskiej kierowanych pod adresem Słonimskiego, aby wyjaśnić przyczynę owego konfliktu i - co za tym idzie - wskazać na właściwy, autorski tekst dramatu, należy porównać obie jego wersje. Na pierwszy rzut oka może się zdawać, że są one pod każdym względem niemal identyczne - w obu wypadkach zastosowano nawet tę samą czcionkę i szerokość kolumn. Przy uważnej lekturze porównawczej, poza nieznaczącymi różnicami w łamaniu, dają się jednak zauważyć trzy rozbieżności:

19 List M. Kuncewiczowej do S. Zahorskiej, 16 czerwca 1945 roku, w: tamże, s. 82-83.

S. Zahorska Smocza 13. Dramat w trzech aktach, "Nowa Polska” 1944 nr 9, s. 604-613 [Słowo wstępne wygłoszone na wieczorze PEN Klubu Polskiego w Londynie, prolog, akt I]; nr 10, s. 654-658 [akt II, akt III, epilog]. 


\begin{tabular}{|c|c|}
\hline Pierwodruk & Wydanie londyńskie \\
\hline \multicolumn{2}{|c|}{ Koniec prologu } \\
\hline In der Heimat, in der Heimat & In der Heimat, in der Heimat \\
\hline Da ist es wunder, wunderschoen.... ${ }^{22}$ & Da ist es wunder, wunderschoen... \\
\hline & (1) \\
\hline & $\begin{array}{c}\text { Wo sind deine Haare } \\
\text { August }\end{array}$ \\
\hline & Deine blonden Jahre \\
\hline & August \\
\hline & Keiner hatte Locken \\
\hline & So wie du \\
\hline & Keine trug die Socken \\
\hline & So wie du \\
\hline & O du lieber Augustin \\
\hline & Alles ist hin23 \\
\hline$[\mathrm{s} .605]$ & [s.7] \\
\hline \multicolumn{2}{|c|}{ Koniec aktu III } \\
\hline Szloma przewala stót, usituje wyrwać nogę od stołu. & Szloma przewala stót, usituje wyrwać nogę od stołu. \\
\hline Birenzweig stoiz rozłożonymi rękami, chwyta krzesto. & Birenzweig stoi z rozłożonym[i] rękami, chwyta \\
\hline Stychaćjęki, lamenty. & krzesto. Stychać jęki, lamenty. \\
\hline $\begin{array}{l}\text { ROTMAN (chwyta się za gtowe) Co to ma zna- } \\
\text { czyć? }\end{array}$ & $\begin{array}{l}\text { ROTMAN (obejmuje głowę oburacz, przechodzi na } \\
\text { środek sceny. Staje wyprostowany.) }\end{array}$ \\
\hline RoTMANOWA (przyczołguje się do niego) & RoTMANOWA (przyczotguje się do niego) \\
\hline [s. 667] & [s. 69] \\
\hline \multicolumn{2}{|c|}{ Epilog } \\
\hline \begin{tabular}{l} 
MAŁY To możemy zrobić wypad. Wielka \\
rzecz... phi... Ja ustawię karabin po drugiej \\
stronie ulicy. Bardzo dobra pozycja. Oni nie \\
podchodzą blisko, jak się pali. \\
\multicolumn{2}{c}{$[$ s. 667] }
\end{tabular} & \begin{tabular}{l} 
MAŁY To możemy zrobić wypad. Wielka \\
rzecz... phi... Ja ustawię karabin po drugiej \\
stronie ulicy. Bardzo dobra pozycja. Oni nie \\
podchodzą blisko, kiedy się pali. \\
\multicolumn{2}{l}{}
\end{tabular} \\
\hline
\end{tabular}

22 Tłumaczenie filologiczne: „Do domu, do domu, / Tam jest wspaniale, pięknie..." [tłum. własne]. Jest to zniekształcony refren niemieckiej piosenki żołnierskiej popularnej w okresie I wojny światowej pt. Nun geht's ans Abschiednehmen (muz. H. Zuschneid, sł. F. Silcher). W oryginale brzmi on: „In der Heimat, in der Heimat, / da gibt's ein Wiedersehn" (tłumaczenie filologiczne: „Do domu, do domu, / tam [powiedzieć] «Do widzenia»" [tłum. własne].

23 Tłumaczenie filologiczne: „Gdzie są twoje włosy / Auguście / Twoje blond lata / Auguście / Nikt nie miał [takich] loków / Jak ty / Nikt nie nosił [takich] skarpet / Jak ty / O, drogi Auguście / Już po wszystkim" [tłum. własne]. Tłumaczenie Własta: "Miał Samsona głowę / August, August / Włosy atłasowe / August, August / Nikt nie miał skarpetek / Tak, jak on / Nikt nie brał kobietek / Tak, jak on / Nikt nie nosił gorsu / Tak, jak on / Nikt nie prężył torsu / Tak, jak on / O, mój Augustynku ty / Zszedłeś na psy" ([partytura]: August. Foxtrot, muzyka R. Fall, słowa Willy [A. Włast], Warszawa [1926]). 
Pierwsza różnica dotyczy dodania w wydaniu książkowym, w zakończeniu prologu, po słowach żołnierskiej piosenki niemieckiej Nun geht's ans Abschiednehmen, refrenu piosenki Wo sind deine Haare, August? Utwór ten skomponował Richard Fall, a słowa do niego napisał Fritz Löhner-Beda. Przetłumaczona przez Andrzeja Własta (właśc. Gustawa Baumrittera) w 1926 roku była jednym z najpopularniejszych utworów sezonu, a wykonywała ją m.in. Zula Pogorzelska w warszawskim kabarecie „Perskie Oko”.

Czy piosenkę tę do dramatu wprowadził Słonimski? Tego, niestety, nie można potwierdzić. Wydaje się to jednak prawdopodobne, jeśli wziąć pod uwagę jego spór z Zahorską - z pewnością bowiem ludyczność tego utworu, potęgowana przez jego, być może, powszechną znajomość wśród polskich wychodźców, do których dramat był w końcu adresowany, znacząco wpływa na wymowę prologu, który - w rezultacie - stał się niemal groteskowy. Konsekwentnie utrzymywany w pierwodruku tragizm tej sceny podtrzymuje jedynie przywołanie piosenki w języku oryginału.

Druga i trzecia różnica, pod koniec trzeciego aktu i w epilogu, mają już charakter stylistyczny; na pewno w istotny sposób nie wpływają na wymowę dzieła. Biorąc zatem pod uwagę, że obie wersje tekstu różnią się znacząco jedynie w prologu, trudno jednoznacznie stwierdzić, czy pierwodruk w „Nowej Polsce” był zgodny z pierwotną, autorską wersją dramatu. Choć wiele na to wskazuje, wątpliwe wydaje się, żeby Zahorska uznała, że Słonimski „zabił książkę” de facto tylko przez dodanie do niej tekstu humorystycznej piosenki. Nie jest to jednak wykluczone, a pytanie o dokładne przyczyny konfliktu pisarki i redaktora musi pozostać otwarte - możliwe bowiem, że w emigracyjnych archiwach znajdują się jakieś materiały, które pomogłyby w udzieleniu na nie odpowiedzi. Tymczasem za podstawę badań i ewentualnego przedruku dramatu zdecydowanie należy uznać jego pierwodruk w „Nowej Polsce”. Tym bardziej, że jest on zgodny z trzecim, dotychczas ostatnim wydaniem utworu - w „Bibliotece Orła Białego”, także z 1945 roku²4. Nie udało się jednak ustalić, czy jego redaktorzy korzystali z pierwodruku z „Nowej Polski”, czy - co mniej prawdopodobne - z rękopisu. Nie sposób przy tym także wyjaśnić, dlaczego nie oparli się na pierwszym wydaniu książkowym, które - w momencie publikacji trzeciego, rzymskiego wydania - było już od kilku miesięcy dostępne ${ }^{25}$.

24 S. Zahorska Smocza 13. Dramat w trzech aktach, Biblioteka "Orła Białego", Rzym 1945.

25 Pierwsze ogłoszenie informujące o możliwości nabycia książki (w cenie 50 lirów): „Orzeł Biały” $1945 \mathrm{nr} 27$ (8 lipca), s. 4. 
W związku z tym zgodność tej edycji z pierwodrukiem niewiele wnosi do prowadzonych tu rozważań ${ }^{26}$.

Kończąc te, niestety, poszlakowe rozpoznania poświęcone okolicznościom wydania dramatu, nie można nie zadać fundamentalnego pytania: dlaczego Zahorska w ogóle zdecydowała się ogłosić swój dramat na łamach „Nowej Polski”? Odpowiedzią zdaje się linia ideowa miesięcznika wyznaczana przez Słonimskiego i jego współpracowników, przede wszystkim Karola Estreichera i Ksawerego Pruszyńskiego, bliska amerykańsko-angielskiemu liberalizmowi, dzięki której:

„Nowa Polska” - jak pisze Adamczyk - stała się miejscem publikacji ważnych dzieł literatury polskiej poświęconej tematyce Holocaustu. Znalazły się na jej łamach teksty pisane na emigracji, począwszy od roku 1942, oraz powstałe w kraju i przedrukowane w latach 1945-1946. Tak charakterystyczna dla emigracji pokusa martyrologicznego współzawodnictwa z żydowską mniejszością zostaje tu zdecydowanie odsunięta na bok. ${ }^{27}$

Należy pamiętać, że Smocza 13 ukazała się na łamach „Nowej Polski” w 1944 roku - wówczas jeszcze Zahorska z pewnością nie zdawała sobie sprawy, w jakim kierunku miesięcznik będzie zmierzał po zakończeniu wojny, że na jego łamach propagowany będzie powrót emigrantów do kraju pozbawionego wolności, którego, rzecz jasna, nie mogła popierać, pozostając do końca życia na obczyźnie. Tym samym w 1944 roku publikacja dramatu na łamach „Nowej Polski" było decyzją w pełni uzasadnioną.

Z przytoczonych ustaleń Adamczyka wynika nadto jeszcze jeden ważny fakt - brak zainteresowania tematyką tragedii żydowskiej wśród polskich wychodźców. O ile bowiem, zdaniem Buryły: „Stosunkowo ubogi zasób tekstów o Szoa,jakie wyszły spod pióra autorów pozostających na uchodźstwie, nie musi budzić zastanowienia"28, o tyle nikłe zainteresowanie Holokaustem jeszcze podczas wojny już może dziwić, a wytłumaczyć je można, tak jak uczynił to Adamczyk, „pokusą martyrologicznego współzawodnictwa”. Na nią właśnie odpowiedziała Zahorska swoim dramatem. Nie można też nie

26 Być może udało by się potwierdzić te ustalenia, porównując pierwodruk dramatu z jego tłumaczeniem, które - jako że według relacji Cybulskiej zlecić je miała Zahorska - mogło opierać się na rękopisie autorki. Jednak ze względu na zaginięcie tego przekładu nie jest to dziś możliwe. 
wspomnieć o antysemickich nastrojach w kraju, które docierały do polskich władz w Londynie i które, jak wolno przypuszczać, prowokowały tych nieobojętnych na los Żydów wychodźców, takich jak Zahorska, do uświadamiania przynajmniej Polakom na obczyźnie ogromu żydowskiej tragedii.

Akcja utworu toczy się 22 i 23 lipca 1942 roku (prolog, akty) i wiosną 1943 roku, podczas powstania w warszawskim getcie (epilog), a wszystkie zdarzenia - poza prologiem - rozgrywają się w kamienicy przy tytułowej ul. Smoczej $13^{29}$. Był to czas w historii getta przełomowy: 22 lipca 1942 roku rozpoczęła się bowiem Grossaktion in Warschau, akcja wysiedleńcza w ramach akcji Reinhardt, mająca na celu eksterminację ludności żydowskiej. Jej szczegóły nie były przez Niemców ujawniane aż do samego końca, o czym mogą świadczyć zapiski w Dzienniku Adama Czerniakowa, prezesa Judenratu, Rady Żydowskiej w getcie. Co prawda, do getta docierały pogłoski o podobnych działaniach na wschodzie (np. w Lublinie), jednak nie dawano im wiary. Czerniaków zanotował tego dnia:

O godzinie 10-tej zjawili się Sturmbahnführer [Herman] Hoefle z towarzyszami. Telefony wyłączyliśmy. Dzieci usunięto z przeciwległego ogródka.

Oświadczono nam, że z pewnymi wyjątkami mają Żydzi, bez różnicy płci i wieku, być wysiedleni na wschód. Dziś do godziny 4 p [o] p[ołudniu] ma być dostarczonych 6000 ludzi. I tak będzie (najmniej) codziennie. [...] Sturmbahnführer Hoefle (Beauftragter [niem. komisarz] do wysiedlenia) poprosił mnie do gabinetu i oświadczył, że żona moja na razie jest wolna, ale jeżeli wysiedlenie się nie uda, pierwsza będzie jako zakładniczka rozstrzelana. ${ }^{\mathbf{3 0}}$

Zdarzenia przedstawione w dramacie są starannie wzorowane na faktach historycznych, ale też bardzo prawdopodobnie oddała pisarka nastroje panujące w tym czasie w getcie - strach potęgowany niepewnością. Sam Czerniaków w Smoczej 13 został przedstawiony jako inżynier Leman i choć nie pojawia się na scenie, jego samobójcza śmierć (23 lipca), wiąże się z całkowitym

29 Nieprawdą jest, jak w recenzji dramatu twierdziłZygmunt Kon, że w lipcu 1942 roku ul. Smocza znajdowała się już poza obrębem getta. Por. Az-t [Z. Kon] Dramat getta i dramat w getcie, "Na Szlaku Kresowej" (Rzym) 1945 nr 10, s. 60.

30 A. Czerniaków Adama Czerniakowa dziennik getta warszawskiego (6 IX 1939-23 VII 1942), oprac. i przyp. M. Fuks, PWN, Warszawa 1983, s. 305-306. 
zwrotem akcji utworu. Należy bowiem pamiętać, że była ona dla warszawskich Żydów aktem ostatecznie potwierdzającym tragiczny los, który miał stać się ich udziałem. Zahorska uchwyciła to doskonale - w pierwszym akcie czytamy bowiem o pogłoskach, którym bohaterowie nie chcą dać wiary:

BirenzWEIG Słyszał pan, panie Rotman, jak powiedziałem, że może doktór sam tu przyjdzie.

Rotman No to co? Po co on ma tu przychodzić?

Birenzweig On się będzie musiał ludziom przyjrzeć. On będzie musiał wybierać.

Rotmanowa Po co wybierać? Kogo wybierać?

BIRENZWEIG ... kazali.

RотмAN Niech pan już mówi! Niech pan już powie!

ЈАкuв [...] Ja słyszałem. Już mówili na mieście.

Rotman Coś ty słyszał?

JAKUB Judenrat ma im przynieść dzisiaj sześć tysięcy Żydów. [...]

Rotmanowa On jest głupi, on nic nie wie. [...]

Rotman Czemuś ty nic nie mówił?

JАKUв Po co ja miałem mówić? [...]

Rotmanowa Ja nic nie rozumiem. To wszystko jest nieprawda....11

Po śmierci Lemana wszystkie wątpliwości mieszkańców Smoczej 13 tracą na znaczeniu, ustępując przekonaniu o rychłej likwidacji getta i ostatecznej zagładzie jego mieszkańców:

BASIA [...] Ja wam jeszcze nie powiedziałam,że inżynier Leman się otruł. [...] Profesorowa Do czego to wszystko zmierza? Dokąd my idziemy?

SzLoma To wszystko zmierza do tego, żeby nas wymordować, to jasne. ЈАКUв ... Nie...

BASIA Jakub ma rację. Przecież zabić wszyscy oni mogą bez pytania się Lemana. Oni chcą czegoś więcej.

Szloma Oni urządzają polowanie na szczury. Jeden sam zjada truciznę, innych oni zabijają.

S. Zahorska Smocza 13. Dramat w trzech aktach, "Nowa Polska” 1944 nr 9, s. 607-608 [akt I]. Dalej wszystkie cytaty z dramatu podano za tym wydaniem, oznaczając je w tekście nazwą partii tekstu i paginacją. Pisownię uwspółcześniono. 
Zahorska przywołuje także inną, ważną dla getta postać - Janusza Korczaka, nazywanego w dramacie Doktorem. W tym wypadku mamy jednak do czynienia ze znaczącym odstępstwem od prawdy historycznej - w dramacie Doktor zostaje „wysiedlony” 23 lipca, zaś Korczak faktycznie przebywał w getcie co najmniej do 4 sierpnia (wskazuje na to ostatni zapis w jego pamiętni$\mathrm{ku}^{32}$ ). Nie jest również prawdą, że Czerniaków mieszkał przy Smoczej 13, ale przy Chłodnej $20^{33}$. Trudno stwierdzić, czy były to przeinaczenia wynikające z nieznajomości przez autorkę faktów, czy też konsekwencja ograniczeń narzucanych przed dramatyczną formę utworu. Nie ma to jednak większego znaczenia w obliczu i tak dużej wartości dokumentarnej dzieła.

Poza osobami dramatu wzorowanymi na postaciach historycznych w utworze występuje wielu wzmiankowanych już bohaterów fikcyjnych, tworzących panoramę społeczną warszawskiego getta. Przy Smoczej 13 juz przed wojną mieszkał Salomon Rotman, bogaty kupiec, i jego żona, nieznana z imienia. Tragarzem u Rotmana był Jakub, ubogi warszawski Żyd, który podczas wojny stracił żonę i syna. U Rotmanów mieszka także Zygmunt Birenzweig, przed wojną przedsiębiorca i kontrahent Rotmana, jego żona Matylda i ich syn Henryk, a także Profesorowa, która owdowiała i której syn jest zapewne żołnierzem, Szloma - robotnik oraz Basia - Polka żydowskiego pochodzenia:

Birenzweig Pan pamięta, jak getto zamurowali? Pan pamięta, ile ludzi było wtedy w getcie?

Rotman Może pół miliona.

BiRENZWEIG Żadne pół miliona. Naprzód było mniej, potem może 600 tysięcy,jak zaczęli zwozić. Przecie wszystkie mieszkania były przepchane, jak, nie przymierzając, to tutaj. Ilu nas tu było w tych dwu pokojach i w tej kuchence? Chyba ze dwadzieścia osób. A teraz...

Umieszczanie Żydów w warszawskim getcie odbywa się jednak do samego końca - w przededniu Grossaktion przybywają bowiem do domu Rotmanów Regina Feigenblat i jej szwagier, piekarz Dawid Stram, pochodzący z małopolskiej Chabówki.

32 J. Korczak Pamiętnik, posł. A. Szlązakowa, Wydawnictwo Poznańskie, Poznań 1984, s. 43.

Zob. A. Czerniaków Adama Czerniakowa dziennik..., s. 233 [notatka z 13 grudnia 1941 roku]. 
Nie oznacza to jednak, że przy Smoczej 13 panują stosunki równościowe status społeczny ma tam znaczenie do samego końca. Świadectwem tego jest wysłanie przez mieszkańców kamienicy Jakuba jako jednego z sześciu tysięcy Żydów „wysiedlonych” 22 lipca, co ma na celu uchronienie pozostałych:

BIRENZWEIG (staje, patrzy niepewnie) Dlaczego pan?

JАKuB Bo ja jestem biedny Żyd.

Profesorowa Wszyscy jesteśmy jednako biedni teraz.

JAкuB Teraz. Ale jak byłem już przedtem.

Rotмanowa On się przyzwyczaił [...]

Rotмan Tobie będzie łatwiej.

[akt I: 612]

Przedstawienia tej nieludzkiej ofiary dopełnia ścięcie brody Jakubowi, co - jak wiadomo - jest dla Żyda nie tylko upokarzające, ale i przywodzi na myśl skojarzenia z postępowaniem hitlerowców. Oczywiście, postawę mieszkańców Smoczej 13, podżeganych przede wszystkim przez Rotmanów, można tłumaczyć ich niewiedzą; krążą wszak pogłoski, że z każdego domu ma być „wysiedlony” jeden Żyd. Nawet kiedy Jakub ucieka z transportu i wraca na Smoczą, nie rozumieją oni, jak haniebnie postąpili:

Rotmanowa A ja wam mówię... Ja wam mówię, że oni jego sami odesłali. Oni potrzebują ludzi do pracy. Oni potrzebują młodych. (wskazuje wokoło) A jemu się w głowie pomieszało ze strachu. On po prostu zwariował. To oni zaraz wiedzieli, że on jest im niepotrzebny i oni go odesłali.

W getcie są także Żydzi zaangażowani w działalność konspiracyjną: Kluger, Gliksman, Mały i Josek Berg, pojawiający się w drugim akcie i powracający w epilogu jako żołnierze Żydowskiej Organizacji Bojowej walczący w powstaniu. Takie nagromadzenie bohaterów, choć z perspektywy kształtu teatralnego dramatu, szczególnie w warunkach wychodźstwa wojennego, może wydawać się niepraktyczne, zdaje się oddawać zamysł Zahorskiej, zmierzającej do ukazania rozmiarów nieomijającej nikogo tragedii.

W związku z tym też problemy warszawskich Żydów nie są eksponowane w scenicznym mikrokosmosie, lecz - sygnalizowane w dialogach - przynależą do teatralnego makrokosmosu. Głód, choroby, niedostępność leków, osamotnione sieroty, trupy leżące na ulicach są w dramacie ukazane jako sprawy 
tak powszechne, codzienne, że ich wspomnienie czy nawet przemilczenie, tak jak chciała Zahorska: „tłumić napięcie, ściszać głosy” [Słowo wstępne ..., s. 604], siłą sugestii tak naprawdę potęguje ogrom tragedii getta.

Owym teatralnym makrokosmosem nie jest jednak Warszawa, lecz getto. Nie okupowany kraj, który zdaje się - mimo i tam dziejących się okrucieństw - przyśniony, wymarzony, ale żydowska enklawa, odgrodzona od miasta murem, za który wyjść mogą tylko wspomnienia. Dychotomia getto - strona aryjska, jak stwierdza Jacek Leociak, jest przy tym charakterystyczną cechą naocznych świadectw Żydów, która: „Stanowi [...] nie tylko najbardziej chyba charakterystyczną cechę ówczesnej przestrzeni miejskiej, lecz także swoistą przestrzeń egzystencji, rozpiętą między «tą» i «tamtą stroną». Osią tej przestrzeni jest mur i on niejako nadaje kształt doświadczeniu"34.

Zahorska wiernie oddaje to w swoim dramacie, czego świadectwem jest choćby rozmowa Profesorowej i Reginy:

REGINA Niech się pani nie irytuje, przecież my niewinni, ja nic nie wiem, ja dopiero od wczoraj w Warszawie, ja tu jeszcze nigdy nie byłam.

Profesorowa Wcale pani nie jest w Warszawie. Pani jest na Smoczej.

[akt I: 6o9]

Te dwa nieprzenikające się, zupełnie inne światy - Warszawę i warszawskie getto - Zahorska próbuje jednak łączyć, gdyż, jak pisała w przedmowie do dramatu:

twardsze od śmierci okazały się [...] prawa braterstwa. Broni dostarczył gettu podziemny ruch polski. Płynęła do getta popod i poprzez dzielące mury. Każdy przemycony ładunek miał cenę niebywale wysoką: cenę narażenia tysięcy żyć ludzkich, może cenę istnienia całej organizacji walki podziemnej. A jednak braterska pomoc - tragiczna pomoc bez nadziei nagrody i zysku - została udzielona.

[Stowo wstepne...: 604]

Ta deklaracja, zdaniem Adamczyka, umniejsza wartość literacką dramatu, choć, jak przyznaje badacz, „autorce przyświeca [...] szlachetny cel propagandowy"35. Buryła z kolei twierdzi, że w tych słowach: „emfaza znajduje się

34 J. Leociak Warszawa okupacyjna-topografia i egzystencja, "Teksty Drugie” 1999 nr 4, s. 24.

35 K. Adamczyk Antysemityzm i nacjonalizm..., s. 100. 
niebezpiecznie blisko kiczu"36. Nie można jednak nie zauważyć, że przedmowa nie koresponduje z drugim aktem dramatu, w którym pojawia się Andrzej - jedyny bohater utworu zza murów getta. Jest to postać dyskusyjna, niejednoznaczna, ponieważ zawodzi nadzieje pokładane w nim zarówno przez żydowskich konspiratorów, jak i przez Basię:

KLUGer Co będzie z bronią? Kiedy dostaniemy broń?

Andrzej Są wątpliwości, czy nie jest za wcześnie na taki... taki gest ostateczny.

GLIKSMAN Ja bym się raczej bał, czy nie jest za późno...

KLUGER My pięknie dziękujemy za czcionki, za artykuły. My chcemy broni. AndRzej Kierownictwo polskiego ruchu nie jest jeszcze zdecydowane... GLIKSMAN Oni się przecie nie będą przejmować tym, że Żydów wymordują. Zginą Żydzi? No to ich nie będzie. [...]

AndRzej My sobie zdajemy sprawę... oceniamy... Mogę was o tym zapewnić. Chodzi o kwestie taktyczne. Czy teraz. Czy już.

Gliksman No pewno. Lepiej poczekać. Jak się w getcie przerzedzi, to i broni trzeba będzie mniej i ryzyko będzie mniejsze...

ANDRzej Mylisz się. Dla nas ryzyko jest zawsze jednako wielkie. Ryzykujemy wszystkim. Całą naszą organizacją.

MAŁY Fetysz organizacji. Co to jest organizacja? To jest środek do celu. ANDRzEj (uśmiecha sie) Organizacja... to jest wszystko, co posiadamy, na razie... to są nasi najlepsi ludzie, nasze państwo, nasz byt dziś i jutro... Czy jesteście pewni, że jeśli rozpoczniecie walkę, to całe getto pójdzie za wami?

[akt II: 656]

Przytoczone słowa to jeden z najbardziej poruszających i zarazem najtrudniejszych dialogów dramatu, w którym mierzą się ze sobą dwie racje nie do pogodzenia. Z jednej strony trudno nie zrozumieć żydowskich bojowników, którzy nawet jeśli nie mają szans na wygraną z nazistami, czego są w pełni świadomi, chcą zginąć z godnością. Z drugiej jednak strony i Andrzej, mimo że swoje argumenty przedstawia raczej nieporadnie („Ja nie umiem gadać!”; akt II: 658), ma rację, przedkładając byt polskiego państwa podziemnego nad życie warszawskich Żydów. Statystyka okazuje się w tym wypadku bezwzględna, tak jak wojskowa dyscyplina, podporządkowanie zwierzchnikom.

36 S. Buryła (Nie)banalnie o Zagładzie, w: tegoż WokółZagłady. Szkice..., s. 94 [przyp. 22]. 
Z równoważącymi się argumentami mamy także do czynienia, gdy mowa o przyczynach, dla których Andrzej nie zabiera Basi z getta. W tym wypadku życie ukochanej Andrzeja przeciwstawione zostaje jego dekonspiracji, choć trudno nie zgodzić się ze stwierdzeniem Popławskiej-Cibickiej, która pisze: „Nie do końca jasne są motywy postępowania Andrzeja - chłopak wspomina o walce zbrojnej, o planowanym wybuchu powstania, o matce, która zginęła w obozie. Swoją niedojrzałość usprawiedliwia wyższą ideą"37.

Podobnie można też przecież rozstrzygać wyższość racji Żydów nad racjami Andrzeja, który niejako sam decyduje o ich życiu i śmierci, będąc z pewnością świadom, jaki będzie finał „wysiedleń”. Zahorska bez wątpienia dostrzegała tę niebezpieczną z punktu widzenia polskiej propagandy dwuznaczność omawianej sceny, stąd też wolno przypuszczać, że zapobiegawczo w przedmowie do dramatu podkreśliła zaangażowanie Polski Podziemnej w pomoc gettu. Jest to tym bardziej prawdopodobne, ponieważ z pewnością wiedziała, jak niewielka była to pomoc ${ }^{\mathbf{3 8}}$.

W niespełna rok po rozpoczęciu Grossaktion, 19 kwietnia 1943 roku wybucha powstanie w getcie warszawskim. Żydzi jako pierwsi podejmują powstańczą walkę z III Rzeszą. Walczą, co jest w dramacie wielokroć podkreślane, nie o zwycięstwo, lecz o godną, ludzką śmierć. Tak też jest przedstawione żydowskie powstanie w epilogu Smoczej 13. Josef Berg wysadza kamienicę - ginie:

Gliksman (cicho) Koniec.

KLUGER Nie. Nie koniec. Za nasze męczarnie, za nasze upodlenie, za śmierć w torturach, za śmierć w płomieniach, za śmierć z głodu, za nierówną walkę, za to, żeśmy wytrwali sami, za to, że zginiemy, walcząc, wystawiamy światu rachunek. Nasze ostatnie strzały są żądaniem zapłaty. Giniemy wolni za wolność.

[epilog: 668]

Ten heroiczny akt Adamczyk odczytuje w perspektywie polskiej tradycji literackiej - jako nawiązanie do Dziadów i, przede wszystkim, do Pana Wołodyjowskiego ${ }^{39}$. Niezależnie od krakowskiego badacza również Popławska-Cibicka dostrzega romantyczne inspiracje epilogu, pisząc:

E. Popławska-Cibicka Zagęszczenie znaczeń w..., s. 424-425.

38 Zob. S. Buryła, D. Krawczyńska Proza, w: Literatura polska wobec Zagłady (1939-1969), red. S. Buryła, D. Krawczyńska, J. Leociak, Wydawnictwo IBL PAN, Warszawa 2016, s. 441.

K. Adamczyk Antysemityzm i nacjonalizm..., s. 101. 
Martyrologiczny ton tej sceny pozwala wpisać dramat w romantyczną konwencję, która często pojawiała się w wypowiedziach artystycznych i publicystycznych twórców związanych z „Wiadomościami” Mieczysława Grydzewskiego. ${ }^{40}$

I dodaje:

Paradygmat romantyczny w dramacie Smocza 13 można zauważyć w kreacji postaw bohaterów, kiedy obserwujemy ich stopniowe dojrzewanie do podjęcia walki zbrojnej. Mieszkańcy ulicy zamieszkiwanej przed wojną przez proletariat i biedotę stają w obronie swojej godności. ${ }^{41}$

Przytoczonym stwierdzeniom badaczki (poza ich „klasowymi” ustępami) trudno odmówić racji, jednak należy podkreślić, że opisywany przez nią stosunek wychodźców wojennych (późniejszych emigrantów) do romantyzmu nie ograniczał się wyłącznie do „polskiego Londynu” oraz, co ważniejsze, nie był wcale jednorodny ${ }^{42}$. Dobrze opracowane są już zagadnienia zarówno dotyczące negacji romantycznych konwencji (np. w twórczości Gombrowicza, Pankowskiego czy Goetla i Herlinga-Grudzińskiego, o których wzmiankuje dalej Popławska-Cibicka), jak i - trudności z udźwignięciem dziedzictwa emigracji polistopadowej (widoczne u Lechonia czy Wierzyńskiego).

Występowanie w dramacie konwencji romantycznej jest w każdym razie oczywiste; warto jednak zadać pytanie o jej znaczenie. Z jednej strony jest ona świadectwem inspiracji literackich Zahorskiej i jednocześnie - zabiegiem wyraźnie wpisującym Smoczą 13 w nurt dramaturgii wychodźczej, heroicznej. Z drugiej jednak mamy do czynienia z jednoznacznym przypisaniem tyrtejskiej postawy Żydom, niejako przeniesieniem jej na znak „więzi braterstwa”. Można w tym wypadku mówić wręcz o zaproszeniu do współuczestniczenia w wyznaczanych przez historię i tradycję losach narodu polskiego, swoistej

E. Popławska-Cibicka Zagęszczenie znaczeń..., s. 425.

\footnotetext{
Tamże. Należy w tym miejscu sprostować, że ul. Smocza, znajdująca się na Muranowie, i owszem, w międzywojniu była zamieszkiwana przez Żydów, ale trudno zgodzić się ze stwierdzeniem, by byli oni wyłącznie przedstawicielami proletariatu i biedoty - ich status majątkowy był bowiem zróżnicowany. Cytowana interpretacja zdaje się tym bardziej nieuzasadniona, jeśli wziąć pod uwagę, że w dramacie Zahorskiej mieszkanie, w którym dzieje się jego akcja, należy do Rotmana - bogatego kupca.

2 Zob. Romantyzm Drugiej Wielkiej Emigracji, red. Ż. Nalewajk i in., Elipsa, Warszawa 2012.
} 
asymilacji w ramach wspólnej tragedii i zajmowanej wobec niej jednakiej postawy utrwalonej w kulturowych wzorcach.

Nie odbywa się to jednak bez poszanowania żydowskiej odrębności, o czym świadczą liczne nawiązania do tradycji biblijnej, przywoływane w dramacie za pośrednictwem motywów Erec Izraela ${ }^{43}$ czy żydowskiego Mesjasza, zdaniem Buryły będącego wręcz jego modelową realizacją ${ }^{44}$. To wszystko czyni ze świata dramatu Zahorskiej, świata oddzielonego murem, enklawę wielonarodowej Polski, w ramach której jest także miejsce na tradycję żydowską. Tym samym Smocza 13 można umiejscowić wśród tych utworów literackich, do których należą przede wszystkim Mickiewiczowski Pan Tadeusz i Żydowie polscy Norwida a które przedstawiają narody polski i żydowski jako nierozerwalnie ze sobą związane.

Pozostaje tu jeszcze poruszyć temat recepcji dramatu Zahorskiej wśród Polaków na obczyźnie, do których był on adresowany. Wszyscy recenzenci pozytywnie ocenili utwór, podkreślając jego dokumentarny charakter, ale i zauważając jego literackie słabości. Kon w „Na Szlaku Kresowej” widział w nim reminiscencje dramatu antycznego, jak i - przedwojennych kabaretów ${ }^{45}$. Terlecki z „Dziennika Polskiego i Dziennika Żołnierza” z kolei twierdził, że „Utwór ma pewne nierówności”46. Podobne zdanie wyraził Schoenfeld na łamach „W Drodze”; krytyk stwierdził jednak, że niedostatki kompozycyjne dramatu wiążą się z jego reportażowym charakterem ${ }^{47}$.

W tej recenzji szczególnej uwagi warte jest jednak przede wszystkim zakończenie, które wiele mówi na temat stosunku wychodźstwa do tragedii warszawskiego getta, ale i - doskonale podsumowuje rozważania zamieszczone w niniejszym szkicu:

Powyższe uwagi krytyczne wobec zamierzenia artystycznego i niektórych szczegółów wykonania nie negują bynajmniej dużych wartości utworu p. Zahorskiej. I jeszcze jedna rzecz, której nie należy pominąć. Głuche milczenie, jakimi pisarze polscy przyjmują tragedię swoich współobywateli i rodaków Żydów, nakazuje tym większe uznanie dla tych, którzy

\footnotetext{
43 E. Popławska-Cibicka Zagęszczenie znaczeń w..., s. 24.

44 S. Buryła Topika Holocaustu. Wstępne rozpoznania, w: tegoż WokółZagłady. Szkice..., s. 72-73.

45 Az-t [Z. Kon] Dramat ghetta i..., s. 60-61.

46 A.J. [T. Terlecki] „Smocza 13". Dramat..., S. 3.

47 H.S. Dominik [H. Schoenfeld] „Smocza 13"..., S. 11.
} 
jak Terlecki czy Zahorska mieli dość serca i odwagi (tak, odwagi!), aby te sprawy - jak wyrzut sumienia - rzucić w twarz światu. I kto wie, czy właśnie ta odwaga, która kazała Zahorskiej wypowiedzieć się tam, gdzie inni znajdują tylko obłudne milczenie, nie przeważy artystycznej niedoskonałości jej utworu ${ }^{48}$.

\section{Abstract}

\section{Jakub Osiński}

NICOLAUS COPERNICUS UNIVERSITY (TORUŃ)

The Poor Emigrants Look at the Ghetto: Stefania Zahorska's Dragon Street 13

Having outlined the genesis and publication history of Stefania Zahorska's play Dragon Street 13 (1944), Osiński interprets the text in the context of various historical events the Grossaktion Warschau, the Warsaw Ghetto Uprising and the attitude of Polish exiled war veterans towards the Holocaust. Scholarship on the play is discussed in the light of recent finding and of reviews of Dragon Street 13 in the émigré press. Thus Osiński reveals the documentary value of Zahorska's text as well as her original contribution to Polish émigré literature.

\section{Keywords}

Stefania Zahorska, World War II, exile drama, Holocaust, Warsaw Ghetto

48 Tamże. 